\title{
PARTISIPASI MASYARAKAT DALAM PENGEMBANGAN KAMPUNG TENUN DI SULAA KOTA BAUBAU
}

\author{
Mimin Trianus ${ }^{1}$ dan Novi Sunu Sri Giriwati ${ }^{2}$ \\ ${ }^{1}$ Arsitektur Lingkungan Binaan, Fakultas Teknik, Universitas Brawijaya, Malang, \\ ${ }^{2}$ Arsitektur Lingkungan Binaan, Universitas Brawijaya, Malang, \\ *minttrianus96@gmail.com
}

\begin{abstract}
ABSTRAK
Pemukiman Sulaa merupakan kampung tenun yang menjadi penghasil kain tenun khas buton terbesar di Kota Baubau. Untuk mengembangkan Kampung Tenun Sulaa ini pemerintah kota Baubau maupun pemerintah provinsi memberdayakan dan melibatkan masyarakat dengan bekerja sama pihak swasta. Dalam penelitian ini kegiatan kerjasama tersebut menjadi kasus dalam melihat tingkat partisipasi masyarakat. Kegiatan yang direncanakan meliputi kegiatan proyek pendirian galeri tenun, bangsal tenun, dan pengecatan rumah masyarakat Sulaa. Penelitian dilakukan dengan metode deskriptif kualitatif. Data dihasilkan dari observasi dan wawancara mendalam kepada tokoh-tokoh penting. Analisis deskriptif merupakan hasil triangulasi sumber data dan dikonfirmasikan dengan konsepkonsep partisipasi. Dalam proyek pembangunan galeri tenun dan bangsal tenun, masyarakat Sulaa tidak turut dilibatkan dalam mendiskusikan ide desain, masyarakat hanya mampu sebatas membuat pengajuan proposal pengadaan wadah untuk tenun yaitu bentuk partisipasi pasif, sedangkan dalam merevitalisasi atau kegiatan pengecatan rumah, masyarakat Sulaa turut dilibatkan untuk berbuat sesuai dengan ide mereka untuk mengecat rumah mereka sendiri, dan membentuk kelompok khusus untuk melukis pada dinding rumah yaitu ditemukan bentuk partisipasi mobilization dalam pelaksanaan. Hasilnya pemberdayaan masyarakat penghasil tenun Buton di Baubau terlihat pada manfaat ekonomi bagi masyarakat berupa meningkatnya jual beli masyarakat luar dan meningkatnya pemesanan sarung tenun khas Buton.
\end{abstract}

Kata kunci: partisipasi masyarakat, pengembangan, Kampung Tenun Sulaa

\begin{abstract}
Sulaa settlement is a weaving village which is the largest producer of -woven fabrics in Buton, Baubau City. To develop this Sulaa Tenun Village, the Baubau government and the provincial government empower and involve the community by cooperating with the private sector. In this study, this collaborative activity becomes a case in seeing the level of community participation. The planned activities include the construction of a weaving gallery, a weaving ward, and painting of Sulaa people's houses. The research was conducted using a qualitative descriptive method. Data generated from observations and in-depth interviews with important figures. Descriptive analysis is the result of triangulation of data sources and confirmed by the concepts of participation. In the weaving gallery construction project and the weaving ward, the Sulaa community was not involved in discussing design ideas, the community was only able to make proposals for the procurement of containers for weaving, namely a form of passive participation, while in revitalizing or painting houses, the Sulaa community was also involved to act accordingly. with their idea to paint their own house, and forming a special group to paint on the walls of the house, namely finding a form of mobilization participation in the implementation. The results of the empowerment of Buton weaving-producing communities in Baubau can be seen in the economic benefits for the community in the form of increased buying and selling for outsiders and an increase in orders for Buton woven sarongs.
\end{abstract}

Keywords: community participation, development, village weaving Sulaa. 


\section{PENDAHULUAN}

Indonesia adalah Negara kepulauan yang kaya akan objek pariwisata yang tersebar dari Sabang sampai Merauke. Perkembangan pariwisata di Indonesia mengalami kemajuan yang pesat sejak pemerintah memutuskan untuk mengandalkan sektor pariwisata sebagai penghasil devisa terbesar bagi Negara. Untuk memudahkan pengembangan pariwisata nasional, maka pemerintah mengambil langkah strategis dengan menyerahkan pembinaannya kepada Pemerintah Daerah Kabupaten/Kota agar lebih memudahkan pengembangan dan koordinasi pembangunan daerah. Salah satu Daerah Tujuan Wisata Sulawesi Tenggara adalah Kota Baubau yang banyak memiliki potensi budaya dan alam. Wisata Budaya dan Pantai yang menarik salah satunya ialah Kawasan Objek Wisata Budaya dan Pantai Sulaa.

Pantai Sulaa sebagai bagian dari Kota Baubau yang memiliki daya tarik untuk dikembangkan sebagai daerah tujuan wisata baik untuk pasar wisata kota maupun dari luar kota, bahkan antar negara. Objek Wisata yang terletak di Sulaa Kecamatan Betoambari Kota Baubau Ini mempunyai potensi sebagai objek wisata budaya yang didukung oleh keberadaannya sebagai suatu kawasan atau kampung tenun tradisional Buton yang ada di kota baubau yang memiliki potensi sangat besar karena merukan salah satu kampung yang termasuk penghasil tenun buton terbesar di Kota Baubau, Yaitu Pesona Budaya dan di dukung dengan pesona dari keindahan alam pantai.

Dalam usaha peningkatan pelayanan terhadap wisatawan tentu saja menjadi tanggung jawab bagi seluruh stakeholder pengembangan objek wisata budaya dan pantai (pemerintah, pihak swasta dari bidang pariwisata maupun masyarakat). Disinilah peran masyarakat belum terlalu optimal dan bahkan tidak dilibatkan, masyarakat disekitar lokasi pariwisata yakni masyarakat Sulaa sebenarnya memiliki potensi yang sangat besar terutama dalam hal menjaga keberlanjutan keberadaan objek wisata budaya dan pantai tersebut. Pelibatan masyarakat secara aktif tentu saja akan memberikan nilai yang baik bagi pemerintah swasta maupun masyarakat sendiri. namun ketika pasif ini tentunya memunculkan masalah dalam berkembangnya wisata budaya tersebut, Di Sulaa telah ada pembangunan galeri dan bangsal tenun, maka dari pembangunan ini ingin menelusuri, mengidentifikasi dan menganalisis bentuk partisipasi masyarakat Sulaa terhadap pembangunan galeri dan bangsal tenun yang terdapat di Sulaa.

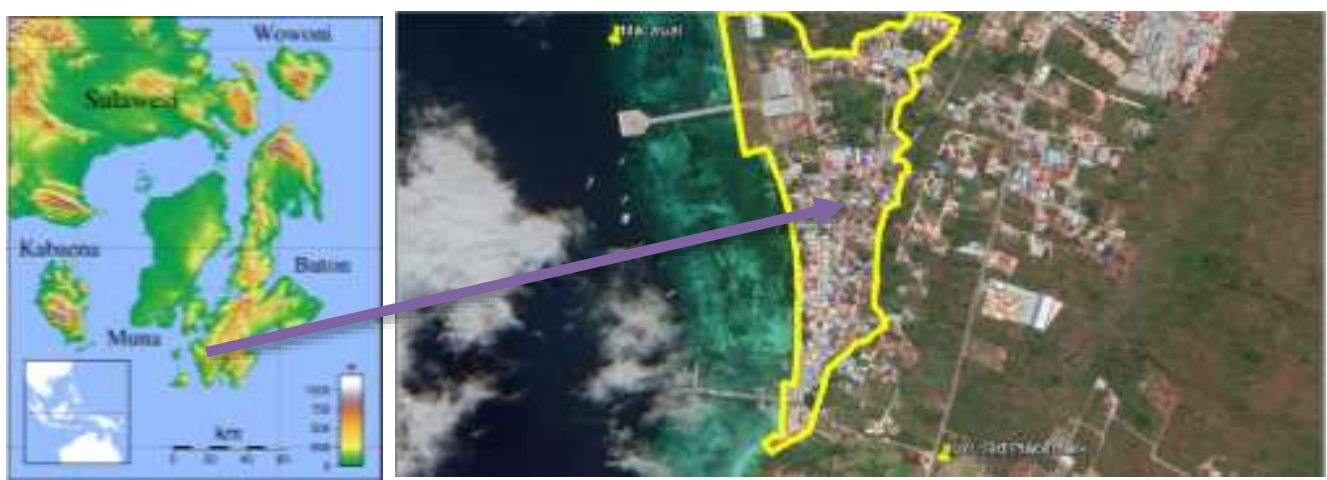

Gambar 1. Peta Sulaa Kecamatan Betoambari Kota Baubau (Sumber: Google Earth, 2020 ) 
Pemukiman Sulaa mempunyai situasi yang unik, karena terkosentrasi di wilayah pesisir yang sekarang tidak sekedar menjadi kampung tenun namun telah menjadi tempat wisata kampung tenun warni warni, kondisi geografis, tanah cenderung datar. Lokus penelitian dengan batas luas administrative $30,75 \mathrm{Ha}$ dari total luas keseluruhan Sulaa $754,36 \mathrm{Ha}$, pemukiman Sulaa meliputi RW1 yang terdiri dari 2 RT dan RW2 terdiri dari 2 RT. Jumlah penduduk dan kepala keluarga berdasarkan data profil kelurahan Sulaa tahun 2014 yitu 1.187 jiwa dan 383 KK. Dengan jumlah rumah sebanyak 293 unit rumah

\section{Partisipasi Masyarakat untuk Pemberdayaan}

Tingkat partisipasi menurut Pretty (1995) bisa dibeda-bedakan dalam 7 (tujuh) tingkatan. Menurutnya tingkatan bersebut menunjukkan pula tipologi partisipasi masyarakat (typology of community participation) yaitu:

1. Manipulative participation; adanya keterwakilan masyarakat dalam kelembagaan pariwisata, namun tidak memiliki kekuasaan.

2. Passive participation; masyarakat hanya diinformasikan hal yang sudah diputuskan atau kejadian yang telah berlangsung.

3. Participation by consultation; masyarakat berpartisipasi dengan cara menjawab pertanyaan yang diajukan pihak eksternal

4. Participation for material incentives; masyarakat memberikan sumberdaya dan kemudian mendapat kompensasi material.

5. Functional participation; pihak eksternal menginisiasi keterlibatan masyarakat dengan membentuk kelompok untuk menentukan tujuan bersama dan terlibat dalam pengambilan keputusan.

6. Interactive participation; masyarakat di berikan fasilitas untuk membuat analisis, merumuskan program dan penguatan institusi lokal setempat.

7. Self-mobilization; masyarakat mempunyai inisiatif sendiri.

Melalui tingkatan dan tipologi tersebut suatu komunitas dapat melakukan evaluasi dan mengambil langkah upaya dalam rangka peningkatan pemberdayaan.

\section{Sektor Pariwisata sebagai Aspek Penggerak Aktifitas Partisipasi}

Pembangunan pariwisata merupakan sektor ekonomi yang mampu berkolaborasi dengan sektor sosial dan ekologi dalam berbagai macam bentuk strategi. Salah satunya dalam wujud pariwisata berbasis masyarakat yang mampu memberikan manfaat dan keuntungan secara ekonomi,sosial budaya dan juga ekologi (Sukandar, 2017). Tujuan dari pembangunan pariwisata seringkali adalah pelibatan atau partisipasi masyarakat itu sendiri yang dengan demikian akan mampu memberikan percepatan pembangunan secara umum (Demartoto, 2009; Ramadhani, 2019).

Unsur-Unsur Pariwisata menurut Spillane ada lima unsur dalam komponen pariwisata yang utama, yaitu:

a. Attractions (daya tarik). Attractions dapat digolongkan menjadi site attractions dan event attractions. Site attractions merupakan daya tarik fisik yang permanendengan lokasi yang tetap yaitu tempattempat wisata yang ada di daerahtujuan wisata seperti galeri.

b. Facilities (fasilitas-fasilitas yang diperlukan). Fasilitas cenderung berorientasi pada daya tarik di suatu lokasi karena fasilitas harus terletak dekat dengan pasarnya. 
c. Infrastructure (infrastruktur). Daya tarik dan fasilitas tidak dapat dicapai dengan mudah kalau belum ada infrastruktur dasar. Perkembangan infrastruktur dari suatu daerah sebenarnya dinikmati baik oleh wisatawan maupun rakyat.

d. Transportations (transportasi). Dalam objek wisata kemajuan dunia transportasi atau pengangkutan sangat dibutuhkan karena sangat menentukan jarak dan waktu dalam suatu perjalanan pariwisata.

Pelaku Pariwisata adalah setiap pihak yang berperan dan terlibat dalam kegiatan pariwisata. Adapun yang menjadi pelaku pariwisata menurut Damanik (2006) adalah :

a. Wisatawan

Wisatawan adalah pengguna produk dan layanan. Wisatawan memiliki beragam motif dan latar belakang (minat, ekspektasi, karakteristik social, ekonomi, budaya, dan sebagainya) yang berbeda-beda dalam melakukan kegiatan isata.Perbedaan tersebut, wisatawan menjadi pihak yang menciptakan permintaan produk dan jasa wisata.

b. Industri Pariwisata/Penyedia Jasa

Industri Pariwisata / Penyedia Jasa adalah Termasuk Dalam kategori ini adalah hotel, restoran, biro perjalanan, pusat informasi wisata, atraksi hiburan, dan lain-lain.

Pelaku Tidak Langsung, yaitu usaha kerajinan tangan, penerbit buku atau lembaran panduan wisata, dan sebagainya.

c. Pendukung Wisata

Termasuk didalamnya adalah penyedia jasa fotografi, jasa kecantikan, olahraga, penjualan, BBM, dan sebagainya.

d. Pemerintah

Pemerintah adalah sebagai pihak yang mempunyai otoritas dalam peraturan, penyediaan, dan peruntukan berbagai infrastruktur yang terkait dengan kebutuhan pariwisata.Tidak hanya itu, pemerintah juga bertanggungjawab dalam menentukan arah yang dituju perjalanan pariwisata. Kebijakan makro yang ditempuh pemerintah merupakan panduan bagi stakeholder yang lain dalam memainkan peran masing-masing.

e. Masyarakat Lokal

Masyarakat Lokal adalah masyarakat yang bermukim di kawsan wisata. Mereka merupakan salah satu pemeran penting dalam pariwisata karena sesungguhnya merekalah yang akan menyediakan sebagian besar atraksi sekaligus menentukan kualitas produk wisata.

f. Lembaga Swadaya Masyarakat (LSM)

Lembaga Swadaya Masyarakat (LSM) merupakan Non Government Organisation (NGO) yang sering melakukan aktivitas kemasyarakatan diberbagai bidang, termasuk bidang pariwisata.

\section{METODE PENELITIAN}

Manurung (2005) mengemukakan teknik analisis deskriptif kualitatif merupakan menganalisis potensi data berdasarkan apa yang dipertimbangkan keahlian dalam bentuk narasi. Ide maupun ungkapan yang ditemukan di lapangan diklarifikasikan dan dikategorikan berdasarkan berbagai tema sesuai dengan fokus penelitiannya. Data dikumpulkan dari hasil observasi, wawancara mendalam, studi 
kepustakaan mengenai bentuk partisipasi masyarakat Sulaal dalam mengembangkan wisata budaya tenun sebagai daya tarik wisata.

Teknik analisis data yaitu analisis data menurut Sugiyono (2009) yang mengatakan proses mencari dan menyusun data yang diperoleh dari hasil wawancara, catatan lapangan, dan bahan penelitian dengan cara sistematis sehingga mudah dipahami dan temuannya dapat diinformasikan kepada orang lain. Data yang dihimpun dari berbagai sumber akan diolah dan dianalisis untuk mengidentifikasikan partisipasi masyarakat di Sulaa. Temuannya dapat diinformasikan kepada orang lain. Data yang dihimpun dari berbagai sumber akan diolah dan dianalisis untuk mengidentifikasikan partisipasi masyarakat di Sulaa Kota Baubau.

\section{HASIL DAN PEMBAHASAN}

Partisipasi masyarakat dalam perencanaan pembangunan, pelaksanaan, dan pemanfaatan hasil pembangunan di Kelurahan Sulaa, Kecamatan Betoambari, Kota Baubau. Rincian mengenai hasilhasil tersebut dapat dilihat dalam uraian sebagai berikut : dalam pembahasan ini terdapat tiga kegiatan yaitu pendirian galeri tenun, bangsal tenun dan pengecatan Rumah warga secara serentak.

\subsection{Kegiatan-Kegiatan Partisipasi Masyarakat Sulaa dalam Pengembangan Kampung tenun} Untuk mengembangkan Kampung Tenun Sulaa ini diselenggarakan tiga kegiatan yakni Pendirian Galeri tenun, Bangsal Tenun dan Pencetan Rumah untuk masyarakat Sulaa. Pada tiga kegiatan yang diselenggaran ini merupakan satu kesatuan rangkaian kegiatan dari pihak pemerintah untuk mengembangkan Kampung Tenun Sulaa berikut rincianya dan penjelasanya :

\subsubsection{Pembangunan Galeri Tenun}

Pada proses pendirian galeri tenun ini di fasilitasi oleh BI, pada tahap perencanaan proyek ini pemerintah provinsi tidak melibatkan masyarakat. Informasi tentang proyek pembangunan galeri tenun telah didengar oleh masyarakat, namun masyarakat tidak memiliki akses dan kewenangan atau kuasa untuk terlibat. Hasil wawancara dengan Pak Gafarudin selaku pengelola galeri serta mewakili masyarakat Sulaa ini menyatakan tidak tahu menahu akan diberikan wewenang untuk mengelola galeri tenun tersebut. Perencanaan yang dimaksud terkait dengan penambahan ruang untuk memperbesar galeri tenun. Desain diserahkan kepada pak Gafarudin selaku wakil dari masyarakat Sulaa untuk membuat desain atau ide untuk desain bangunan galeri tenunnya.

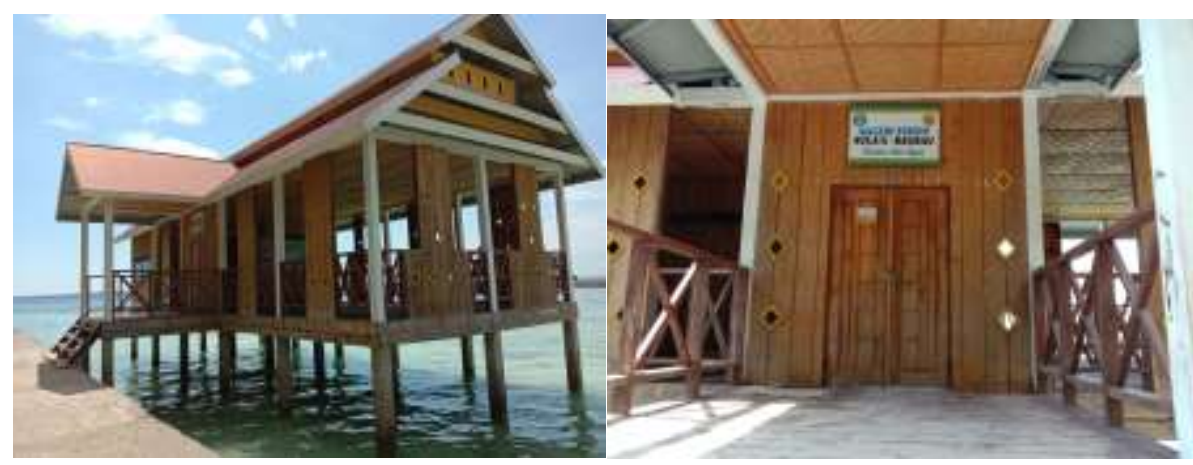


Gambar 2. Galeri Tenun (Sumber:; 2020 )

Gambar diatas merupakan gambar dari galeri tenun yang telah digunakan oleh masyarakat saat ini, Pada saat wawancara di lapangan masyarakat mempertanyakan bahkan memprotes terkait volume ruang pada galeri tenun karena terkait kapasitas jumlah penenun dan wisatawan atau pengunjung yang datang serta ruang untuk memamerkan hasil karya tenun tidak di persiapkan ruang khusus. Dengan demikian hasil desain belum mencerminkan terakomodirnya kebutuhan masyarakat Kampung Tenun Sulaa.

\subsubsection{Pembangunan 9 Bangsal Tenun}

Bangsal tenun ini merupakan hasil dari pekerjaan yang dilakukan oleh kontraktor yang difasilitasi oleh pemerintah, Dinas Perdagangan dan Perindustrian Kota Baubau, dengan penenganan pelaksanaan pekerjaan bangsal tenun oleh pihak kontraktor yaitu CV. Mudabbir . kegiatan proyek ini dilakukan pada tahun 2017 lalu. Dengan anggaran Rp. 1.356.848.000,- dengan jumlah titik bangsal tenun yang dibangun yaitu 9 unit bangsal tenun,

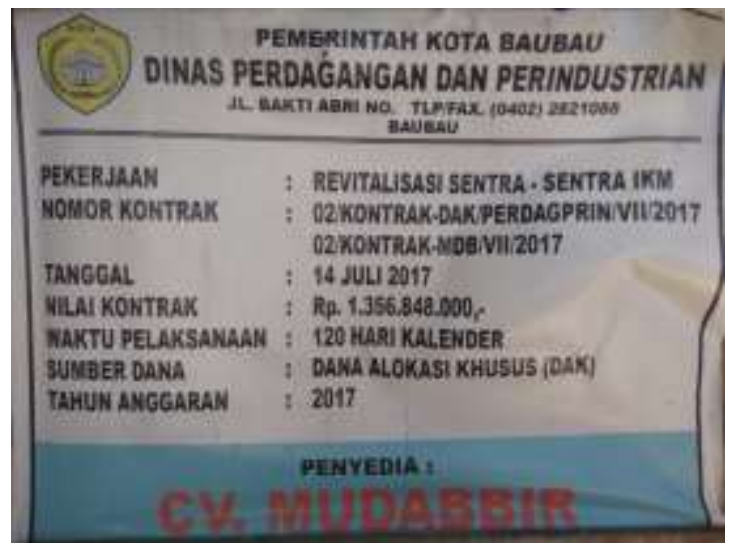

Gambar 3. Papan Proyek Pekerjaan Bangsal Tenun (Sumber:, 2020) 


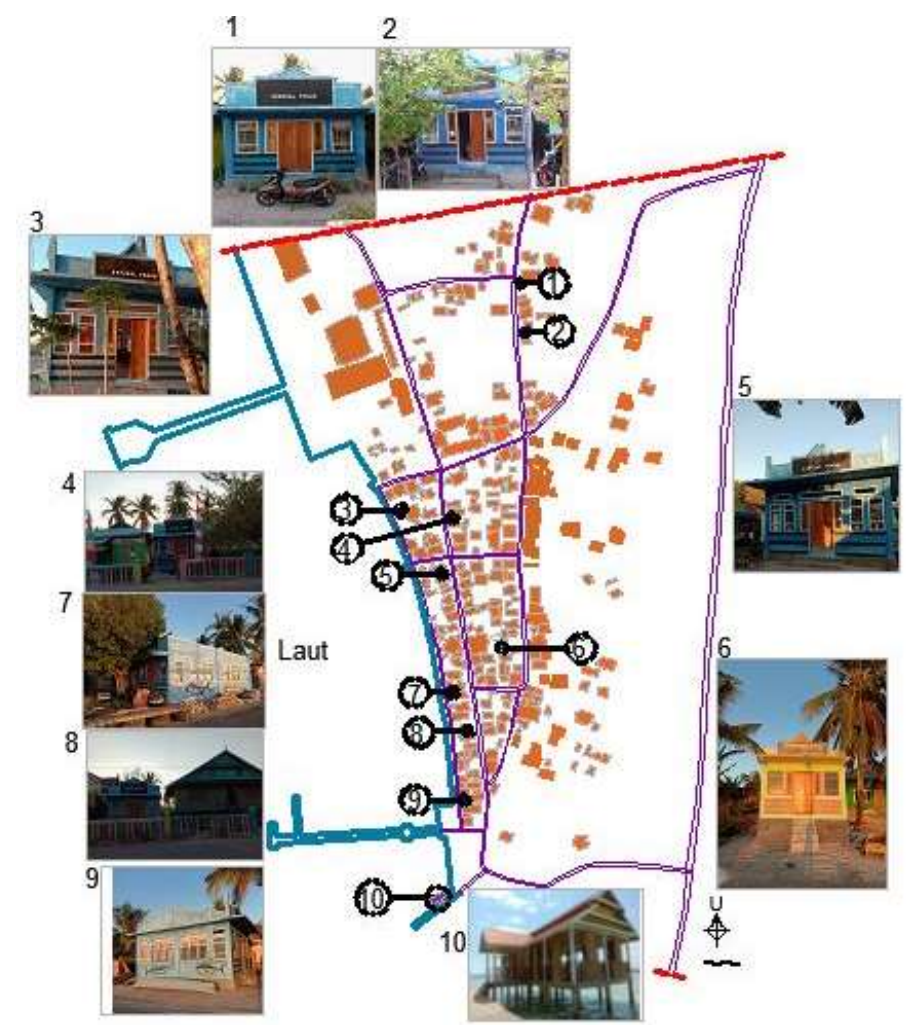

Gambar 4. Bangsal Tenun Sulaa (Sumber: Dokumentasi dan Analisis, 2020)

Dalam proses pendirian Bangsal tenun pada mulanya diawali dengan pengajuan proposal oleh ketua RT yang bernama pak Gafarudin selaku yang mewakili masyarakat Sulaa. Tentunya dari pengajuan proposal tersebut ada harapan bahwa, dari pengajuan proposal ini ke pihak kelurahan dari masyarakat bila tercapai atau dissetujui pengajuan proposal tersebut maka harapanya masyarakat ikut terlibat, namun ketika proposal tersebut telah disetujui, namun pada proses perencanaanya dan pelaksanaanya di lapangan pihak kelurahan atau pemerintah tidak ikut atau turut melibatkan masyarakat dalam perencanaan untuk ide desain atau pendapat, sekiranya dalam teori yang di kemukakan rapoport sendiri bahwa masyarakat setempatlah yang mengenal lingkungan mereka sendiri. Masyarakat dilibatkan hanya pada permohonan pengajuan proposal, waktu pelaksanaanya yaitu hanya pada saat musrembang, wakil masyarakat ikut dilibatkan untuk pengajuan pendapat, namun disisi lain juga karang taruna dan LPM Sulaa tidak begitu peduli dan tidak begitu harmonis dengan pihak kelurahan dalam rencana kegiatan, karang taruna Sulaa hanya berfokus kepada kegiatan olahraga 


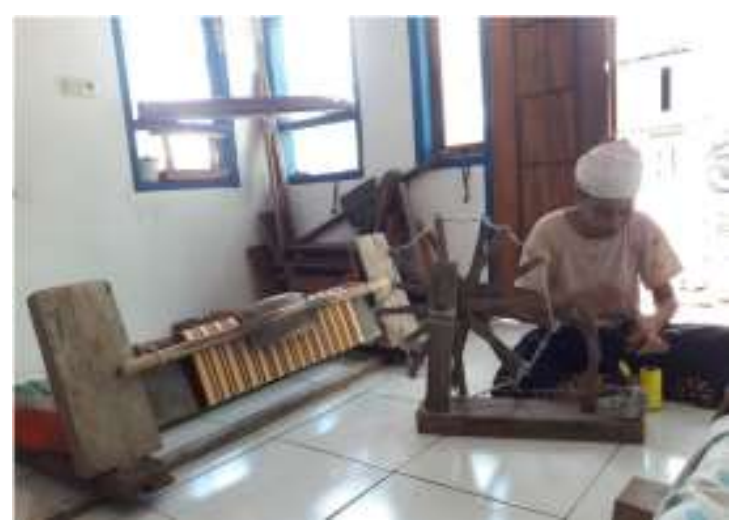

Gambar 5. Penggunaan Bangsal Tenun (Sumber: Dokumentasi, 2020 )

\subsubsection{Pengecatan Rumah Kampung Tenun Sulaa}

Kegiatan Pengecatan rumah ini merupakan kegiatan dari pemerintah yang memfasilitasi adalah pihak swasta yaitu dari pasific Paint, Glotex. Kegiatan ini dilakukan pada tahun 2018 lalu, yang dimana dengan kegiatan pengecatan ini Kampung Tenun Sulaa berubah nama menjadi kampung tenun warna warni.

Gambar 6 dan 7 merupakan hasil dari karya masyarakat dan tim. Partisipasi masyarakat dalam perencanaan, secara menyeluruh berperan aktif, keikutsertaan masyarakat dalam menyumbangkan pemikiran ide / pertanyaan / gagasan sebagai wujud dalam memberikan kontribusi dalam desain dan pelaksanaan dalam pengecatan mereka melakukanya sendiri. Dari hasil penelitian yang penulis lakukan dalam penyerapan aspirasi masyarakat, bentuk usulan dari masyarakat Kelurahan Sulaa tersebut kebanyakan disampaikan melewati pihak Ketua RT yakni Pak Gafar, dilanjutkan ke Kelurahan dan kemudian akan dibahas dan ditentukan sesuai dengan prioritas dan kemudian akan diteruskan ke Kecamatan. Namun ketika masuk proses perencanaan dan pelaksanaan masyarakat ikut dilibatkan dalam melakukan pengecatan di rumah mereka sendiri dan ada satu tim yang dibentuk untuk melukis dinding. Hal ini menunjukkan tingkat partisipasi masyarakat dalam pelaksanaan sangat antusias dan masyarakat sendiri yang berkreatif.

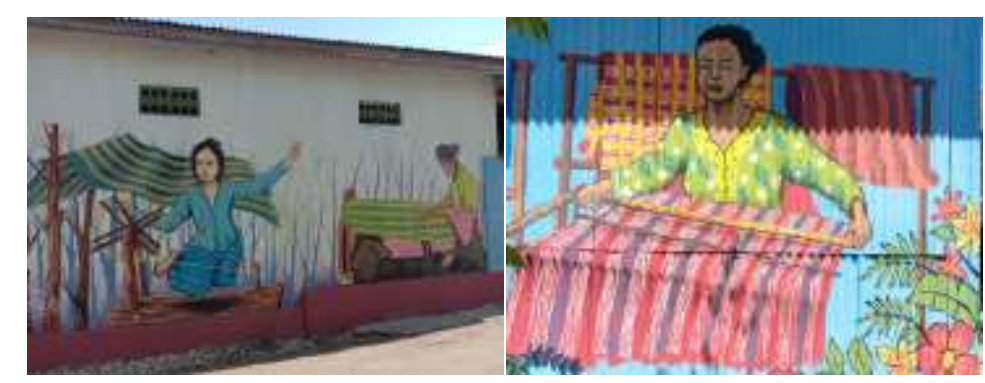




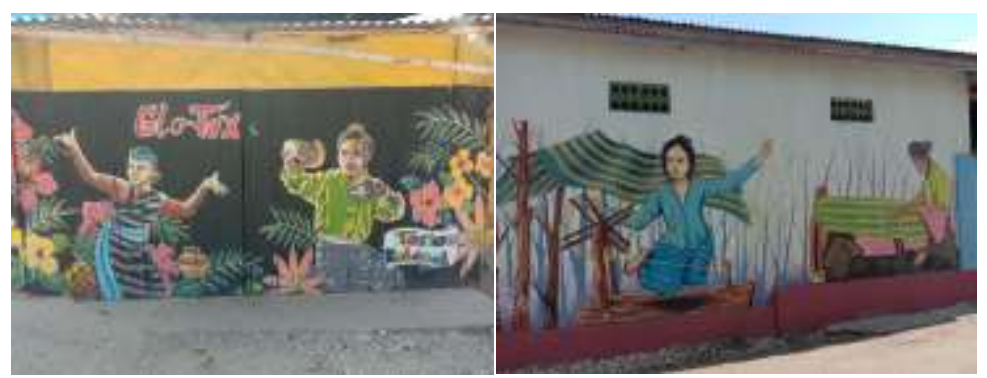

Gambar 6. Lukisan Pada Dinding (Sumber: Dokumentasi, 2020)

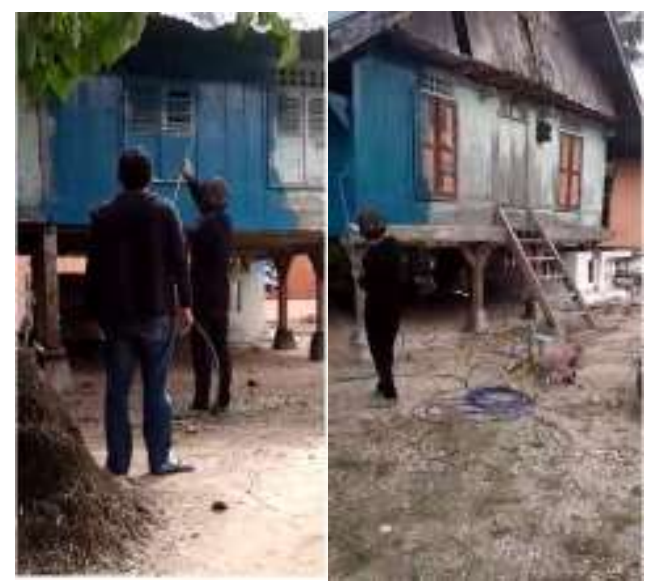

Gambar 7. Proses Pengecatan Rumah (Sumber: Dokumentasi dan Analisis, 2020)

Pada proses peresmian Kampung Tenun Sulaa menjadi kampung tenun warna warni. Masyarakat ikut terlibat dalam menyambut para pengunjung atau wisatawan dan pihak swasta srta pemerintah dengan menggelar ataraksi tarian buton untuk menerima tamu. Tarian ini merupakan bentuk partisipasi masyarakat dalam menerima tamu.

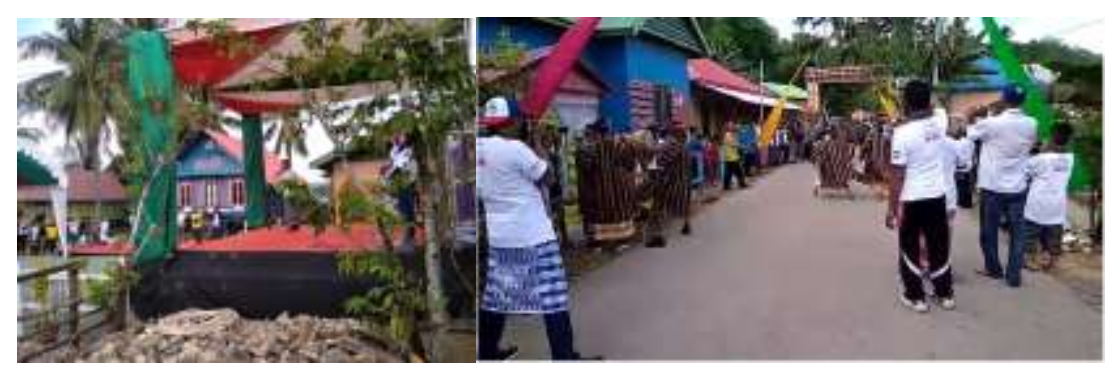

Gambar 8. Peresmian Kampung Tenun Warna Warni Sulaa (Sumber: Dokumntasi Gafar, 2018) 


\subsection{Tingkatan Partisipasi Masyarakat}

\section{Partisipasi pasif}

Dari hasil identifikasi dan analaisis menemukan bahwa partisipasi passif ditemukan pada kegiatan pembangunan galeri tenun dan bangsal tenun., Disebut partisipasi pasif menyangkut tentang keterlibatan masyarakat tidak ada dalam perencanaan dan pembangunan secara baik, pada seharusnya masyarakat harus dilibatkan, karena masyarakatlah yang mengetahui tentang tempat mereka itu sendiri, yang sesuai dengan yang ingin dirasakan masyarakat.

\section{Partisipasi Self Mobilization}

Dari hasil pengamatan di lapangan lalu dianalisis, partisipasi mobilization terdapat pada pelaksanaan pengecatan pada rumah, yang dikreasikan oleh masyarakat pribadi tanpa ada intervensi dari luar, dan dalam prosesnya ada konsultasi dengan pihak RT, maka dalam proses perencanaan dan pelaksanaan berada pada tingkatan self mobilization dan consultatif, hal ini terjadi karena masyarakat dalam proses perencanaan tidak dilibatkan.

\section{SIMPULAN}

Partisipasi masyarakat dalam pembangunan di Kelurahan Sulaa, Kecamatan Betoambari, Kota Baubau, yang telah diuraikan sebelumnya, maka penulis dapat menyimpulkan beberapa hal dalam penelitian ini, di antaranya: terdapat perbedaaan tingkatan partisipasi dalam 3 kegiatan dalam pengembangan Kampung Tenun Sulaa.

Pendirian Galeri Tenun yaitu termasuk dalam tingkatan partisipasi passive sedangkan untuk pendirian Bangsal Tenun juga begitu termasuk dalam tingkatan partisipasi pasif, sedangkan dalam kegiatan pengecatan rumah Kampung Tenun Sulaa masuk dalam tingkatan partisipasi self mobilization dalam proses pelaksanaan pengecatanya, namun dengan selesainya kegiatan ini tentunya walaupun masyarakat tidak cukup terlibat namun dalam penggunaan pengelolaan galeri tenun dan bangsal tenun mempunyai manfaat buat masyarakat Sulaa.

Rekomendasi untuk keterlibatan masyarakat: pemerintah dapat mengadakan grup diskusi antara pihak kelurahan, pemerintah, masyarakat, maupun pihak swasta, melalu FGD dan workshop, agar sesuatu bisa dibicarakan dengan baik terhadap masyarakat Saran untuk masyarakat, pemerintah kelurahan Sulaa, pihak swasta, yang paling bekerjasama dengan baik, dan terlebih kepada pihak kelurahan ada baiknya bisa dapat melibatkan masyarakat dalam kegiatan apapun, dapat menghimbau dan saling memberi saran dan masukan untuk pengembangan Kampung Tenun Sulaa.

\section{REFERENSI}

Damanik, J., Weber H.F. (2006). Perencanaan Ekowisata. Yogyakarta. Puspar UGM dan Andi Yogyakarta.

Demartoto, A. (2009). Pembangunan Pariwisata Berbasis Masyarakat. Surakarta: Sebelas Maret, UniversityPress.

Kadir, I., Djunaedi A., Sudaryono, Wibisono B. H. (2015). Nilai-nilai budaya dan bangunan arsitektur local dalam penciptaan dan penggunaan ruang di Permukiman Sulaa Baubau Sulawesi Tenggara: The finding the fifth element.

Kadir, I., Djunaedi A., Sudaryono, Wibisono B. H. (2015). Perubahan Pola spasial Pemukiman Sulaa pasca reklamasi. Forum Teknik. 
Kadir, I., Tahir M..A., Said B.(2018. Penggunaan Ruang Berbasis Kearifan Lokal di Permukiman Pesisir Sulaa Baubau. Teknologi terapan berbasis kearifan lokal (snt2bkl).

Kadir, I., Tahir M.A. (2019). Konsep eksistensi ruang budaya permukiman pesisir Sulaa di kota baubau. Jurnal Malige Arsitektur.

Manurung, H. (2005). Metode Penelitian. Jakarta.

Pretty, J.N. (1995). Participatory Learning and Action; A Trainer's Guide. 267pp, ISBN:189825002, HED. Ramadhani, A.N. (2019). Community Based Tourism Dalam Pengembangan Kampung Nelayan Kedung Cowek Di Surabaya. Mintakat Jurnal Arsitektur, 20(2). 55-65.

Sukandar, P.A. (2017). Menggagas Pelestarian Permukiman Tradisional Dusun Sade Sebagai Lansekap Budaya Yang Mampu Mengantisipasi Kebutuhan Penghuninya. Mintakat Jurnal Arsitektur, 18(2).

Sugiyono. (2009). Metode Penelitian Kuantitatif, Kualitatif dan R\&D, Bandung : Alfabeta.

UU RI No.10 Tahun .(2009). Undang-undang tentang kepariwisataan. 